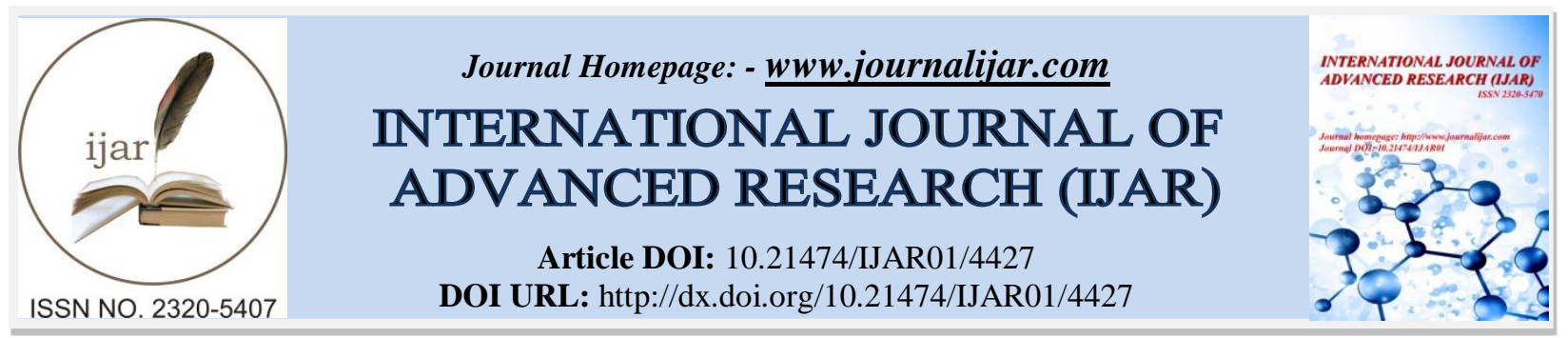

RESEARCH ARTICLE

\title{
THE EFFECT OF ORGANIZATIONAL CULTURE AND MIDWIFE COMPETENCY ON MIDWIFE PERFORMANCE STUDY MIDWIFE AT COMMUNITY HEALTH CENTRE IN JAMBI PROVINCE.
}

\author{
Dr. Risnita, M.Pd ${ }^{1}$, Prof. Dr. Mukhtar ${ }^{2}$ and Dr. Wirda ${ }^{3}$. \\ 1. Lecturer of Postgraduate Program, State Islamic University (UIN STS), Jambi Indonesia. \\ 2. Professor and Director of Postgraduate Program, State Islamic University (UIN STS), Jambi Indonesia. \\ 3. Postgraduate Doctoral Program, State Islamic University (UIN STS), Jambi Indonesia.
}

\section{Manuscript Info}

Manuscript History

Received: 09 April 2017

Final Accepted: 11 May 2017

Published: June 2017

Key words:-

$\backslash$ Organizational Culture, Midwife

Competency, and Midwife Performance.

\section{Abstract}

This study aims to analyze the influence of Organizational Culture and Midwife Competency on the Midwife Performance of either partially or simultaneously at Community Health Centre in Jambi Province. The population in this research is midwife at Community Health Centre in Jambi Province which represent 3 area that is Bungo Regency, Merangin Regency and Regency of Tanjung Jabung Barat with 391 midwives. The determination of the sample was determined based on the theory developed by Slovin. Based on the formula of determining the number of samples from Slovin obtained the number of samples (n) as many as 80 people with value e $=10 \%$. Quantitative analysis method using path analysis, followed by determination analysis ( $\mathrm{R}$ Square), partial hypothesis testing ( $\mathrm{t}$ test) and simultaneous ( $F$ test) with alpha 5 percent $(0,05)$. Before further analyzed first, the requirements analysis test is done. Analyze tool using SPSS version 21.0 for windows. The results showed that the Organizational Culture and Midwife Competency had a positive and significant effect on Midwife Performance at Community Health Centre in Jambi Province.

\section{Introduction:-}

Health development is an effort to fulfill one of the basic rights of the people, namely the right to obtain health services. In the implementation of health efforts, mothers and children are family members who need to get priority. Therefore, efforts to improve maternal and child health receive special attention.

Maternal and child health and well-being is the most important concern for the midwife. Midwives in providing health services are responsible and accountable for their practice. Based on information from the Ministry of Health $(\mathrm{MOH})$ in 2008, the Maternal Mortality Rate (MMR) in Indonesia is high compared to other ASEAN member countries, as shown in the following table.

Table 1:- Number of Maternal Mortality Rate (MMR) ASEAN member states in 2008.

\begin{tabular}{|c|c|c|}
\hline No & Negara & Angka Kematian Ibu (AKI) \\
\hline 1 & Singapore & 6 out of 100.000 Live Births \\
\hline 2 & Malaysia & 160 out of 100.000 Live Births \\
\hline
\end{tabular}




\begin{tabular}{|l|c|c|}
\hline 3 & Vietnam & 160 out of 100.000 Live Births \\
\hline 4 & Philippines & 112 out of 100.000 Live Births \\
\hline 5 & Brunei Darussalam & 33 out of 100.000 Live Births \\
\hline 6 & Thailand & 1 out of 100.000 Live Births \\
\hline 7 & Indonesian & 228 out of 100.000 Live Births \\
\hline
\end{tabular}

Source: https://midwifecare.wordpress.com/2012/02/21/sekitar-20-30/

From the table above, it can be seen that the maternal mortality rate (MMR) in ASEAN member countries is quite high, whereas the lowest MMR is in Thailand, which is 1 out of 100,000 live births, while the highest MMR is in Indonesian which is 228 out of 100,000 live births. According to the MOH in 2010 the direct cause of maternal deaths in Indonesian related to pregnancy and childbirth, especially the $28 \%$ bleeding. Other reasons are eclampsia $24 \%$, infection $11 \%$, old partus $5 \%$, and abortus $5 \%$.

The high rate of MMR in Indonesia of course should receive special attention from the government, because if this is not immediately get serious handling it is feared that the mortality rate will increase steadily and will find it difficult to achieve the target of decreasing maternal mortality rate according to MDG's target.

One way to reduce MMR in Indonesia is by providing midwifery services by competent personnel, having high performance and having knowledge and or skill through health education which for certain types require authority to make health efforts.

According Sembiring (2012:81) performance is a description of the level of achievement of the implementation or activity/program/policy by using a number of resources in achieving organizational goals. Further Wibowo (2013: 7) describes the performance is an implication of the plan that has been prepared implementation of performance performed by human resources who have the ability, competence, motivation and interests.

In theory there are so many factors that relate to one's performance. These factors may be sourced from the environment (including the organization) as well as the factors that come from within the employees themselves. Environmental factors can be sourced from the organization, among others is the organizational culture, while factors derived from the employee itself one of them is the character, behavior and personal qualifications of employees who in this case implemented in the form of competence.

Organizational culture is a value system held and carried out by members of the organization, so that such a thing can distinguish the organization with other organizations (Robbins, 2010:525). Organizational culture becomes the norm, trust, value and practice to all members of the organization. This includes the ways in which a person communicates within an organization such as calling the name of a co-worker, the way of speaking, dressing, the value of work, and so on.

Organizational culture can affect a person in behaving, how to work and how to describe the work. Without an organizational culture, one tends to feel reluctant to perform a task well regardless of its status within the organization, due to a lack of commitment agreement (Porwani, 2010). So that a person's high performance is strongly influenced by organizational culture factor. The concept of organizational culture is one tool to improve performance, because organizational culture affects the mindset, feelings and the way a person acts in an organization (Maslukhan, F, 2015).

This is also supported by the results of research conducted by Ahmad (2016), Judge, A., and Hadipapo, A. (2015), Taurisa, CM, and Ratnawati, I. (2012), Maslukhan, F. (2015) And Porwani, S. (2010) which states that organizational culture has an influence on performance. This means that by having a strong organizational culture, a person will be able to perform a task well, so that will be able to optimal work results.

Furthermore, as for other factors related to employee attitude is competence. Competence is an ability to perform or perform a job or task based on skills and knowledge and supported by the work attitude demanded by the job. Spencer and Spencer (2010:9) propose competence as a basic characteristic of an individual causally related to criterion referenced effective and/or high performance and a job or situation. 
Competence is basically a fundamental characteristic of each individual associated with the referenced criteria of superior or effective performance in a job or situation. Several previous studies have proved that competence has influence on performance, such as research conducted by Aima, Havidz and Ali, Hapzi, et al (2017), Rinawati, SI and Ingsih, K (2013), Suswardji, E., Hasbullah, R., and Albatross, E (2012), Dhermawan, AANB, Sudibya, IGA, and Utama, IWM (2012), and Linawati and Suhaji (2012) where the research results suggest that competence will be able to influence and improve performance. This means that having a good competence will be able to improve performance to give maximum results.

Based on the background and the problem then the goal to be achieved from this research is:-

1. Analyzing the influence of organizational culture on midwife performance partially.

2. Analyzing the influence of midwife competence on midwife performance partially.

3. Analyzing the influence of organizational culture and midwife competency on midwife performance simultaneously.

\section{Literature Review:-}

\section{Midwife Performance:-}

Performance derived from the understanding of performance or job performance is the performance of work shown someone in completing the work. Performance is also always associated with the responsibility and achievement of organizational goals. Wibowo (2011:7) describes the performance comes from the definition of performance, there is also a definition of performance as a result of work or performance, but in fact performance has a broader meaning, not just the work, but including how the work process takes place.

Wilson (2012: 231) defines performance is the work achieved by a person based on job requirements. Meanwhile, according to Sembiring (2012: 81) performance is a description of the level of achievement of implementation or activity/program/policy by using a number of resources in achieving organizational goals.

While the meanings of midwives by their understanding and midwives are internationally recognized by the International Confederation of Midwives (ICM) in 1972, and the International Federation of Gynecologists of Obstetrics (FIGO) in 1973, the WHO and other bodies are those who have completed the midwifery education program Recognized by the state and qualified and given permission to practice midwifery practice in the country. She should be able to provide supervision, upbringing and advice to women during pregnancy, childbirth and postpartum, leading childbirth on her own responsibilities and care for newborns and children.

Based on the theories that have been described, it can be synthesized that the intent with the performance of midwives in this study is the result of work and behavioral changes and the character of midwife in carrying out their work in accordance with expectations, increasing the number of life of mothers and children in health centers in the health of Jambi province in accordance with Standard The predefined Operating Procedures. The indicators of the performance of the midwife are: 1) Deepening of religion and profession, 2) trust in work, 3) Behavior in work, 4) Job opportunities, 5) Achieving good in work 6) Effectiveness and Work result 7) Work efficiency.

\section{Organizational Culture :-}

Organizational culture plays a very important role in the achievement of corporate goals. Organizational culture is also said as a pattern of behavior that has been accepted by all members of an organization. Schein in Vecchio (2007: 618) suggests that organizational culture is the philosophy that underlies organizational policies, rules of association, and the feelings or climate brought about by the physical preparation of the organization.

Organizational culture becomes the norm, trust, value and practice to all members of the organization. This includes the ways in which a person communicates within an organization such as calling the name of a co-worker, the way of speaking, dressing, the value of work, and so on. Luthans (2009:125) says that organizational culture must have recognized and respected behavioral order characteristics, the existence of norms, dominant values, philosophy, rules and organizational mood. Furthermore, Robbins (2010:525) explains that organizational culture is a value system held and conducted by members of the organization, so that such a thing can distinguish the organization with other organizations.

Organizational culture according to Kreitner and Kinicki (2014: 60) has four functions namely a) organizational culture will give its members the identity of the organization, b) Provide facilities in mutual commitment, c) support 
a stable social system and d) shape the behavior of its members with sensitivity to its environment . Meanwhile, Vecchio (2007: 618) provides the definition of organizational culture as the values and norms shared in an organization and teaches the workers who come.

The organizational culture consists of various aspects and the most important aspect is value. Something that is believed to be true. Value is what it deserves to exist and is perceived by all individuals within an organization. Visible values will tell us what is important in the organization and what needs attention. Organizational culture as a system of shared meanings adopted by members is what distinguishes one organization with another organization. In developing organizational culture, a very important factor is the value of qualified human resources. And this can be seen from the results of his work in terms of professionalism of good performance that is how an employee is able to show professional work behavior and lead to the values of organizational culture to Islamic, in order to achieve the goals and objectives of the organization.

Based on the theory that has been described, it can be synthesized that what is meant by organizational culture in this research is related to beliefs, norms, habits, and shared values that become characteristic to do in organization. The indicators of organizational culture are: a) Organizational Rules b) Orientation on the environment c) decisionmaking style.

\section{Midwife Competencies :-}

Competence is an ability to perform or perform a job or task based on skills and knowledge and supported by the work attitude demanded by the job. Thus, the competence shows the skills or knowledge characterized by professionalism in a particular field as the most important, as the seed of the field. Competence is a fundamental characteristic of each individual associated with the referenced criteria of superior or effective performance in a job or situation. According to Spenser and spencer in Wibowo (2011:87) states that competence is the basic foundation of the characteristics of people and indicates how to behave or think, equalize the situation, and support for a long period of time.

Midwife competencies based on the Central Board of Indonesian Midwife Association include the knowledge, skills and behavior that midwives must have in securing safe midwifery practices and responsibilities in various health care settings. The competence of the Indonesian midwife was arranged in reference to the Minister of Health Number 572 of 1996 on the registration and practice of the midwife and the midwife competency composed by ICM February 1999.

The standard of midwife profession is regulated in the decision of the minister of health of the Republic of Indonesia Number: 369/MENKES/SK/III/2007. This midwife profession standard regulates midwife competency standards, midwife education standards, midwifery standards and midwifery standards. The purpose of midwife's professional standard is to ensure safe and quality services, and as a foundation for standardization and professional development of midwives. The competency standards that a midwife must possess include the requirements of knowledge and skills, public health and ethics that form the basis of quality care that is culturally appropriate, for women, newborns and their families.

Based on the theory that has been described, it can be synthesized that the meaning of midwives competence in this study is the skills of midwives perform work based on skills supported by experience in the midwifery work. The indicators of midwife competence are: a) knowledge, b) skills and c) behavior.

\section{Conceptual Framework :-}

Performance is a description of the level of achievement of the implementation or activity/programe/policy by using a number of resources in achieving organizational goals (Sembiring, 2012: 81). Further Wibowo (2013: 7) describes the performance is an implication of the plan that has been prepared implementation of performance performed by human resources who have the ability, competence, motivation and interests.

In theory there are so many factors that relate to one's performance. These factors may be sourced from the environment (including the organization) as well as the factors that come from within the employees themselves. Environmental factors can be sourced from the organization, among others is the organizational culture, while factors derived from the employee itself one of them is the character, behavior and personal qualifications of employees who in this case implemented in the form of competence. 
Based on the study of theory and previous studies, can be drawn relationships between variables of organizational culture have an effect on performance. This is put forward by Maslukhan, F (2015) in his research that suggests organizational culture is one tool to improve performance, because organizational culture affects the mindset, feelings and the way a person acts within an organization. So that a person's high performance is strongly influenced by organizational culture factor. In addition Porwani (2010) also suggests organizational culture can affect a person in behaving, how to work and how to describe the work. Without an organizational culture, one tends to feel reluctant to perform a task well regardless of its status within the organization, due to a lack of commitment agreements.

Furthermore, as for other factors related to employee attitude is competence. Spencer and Spencer (2010:9) argue that competence is a basic characteristic of an individual causally related to criterion referenced effective and/or high performance and a job or situation.

In addition, some studies that have been done previously have proved that competence has influence on performance, among them are research conducted by Aima, Havidz and Ali, Hapzi, et al (2017), Rinawati, SI and Ingsih, K (2013), Suswardji, E., Hasbullah, R., and Albatross, E (2012), Dhermawan, AANB, Sudibya, IGA, and Utama, IWM (2012), and Linawati and Suhaji (2012) where the results of his research argue that competence will be able to influence and improve Performance. This means that having a good competence will be able to improve performance to give maximum results.

Based on the above explanation of the flow of thinking between research variables with reference to the results of previous research and expert opinion, it can be described through the framework of research models such as the following figure:

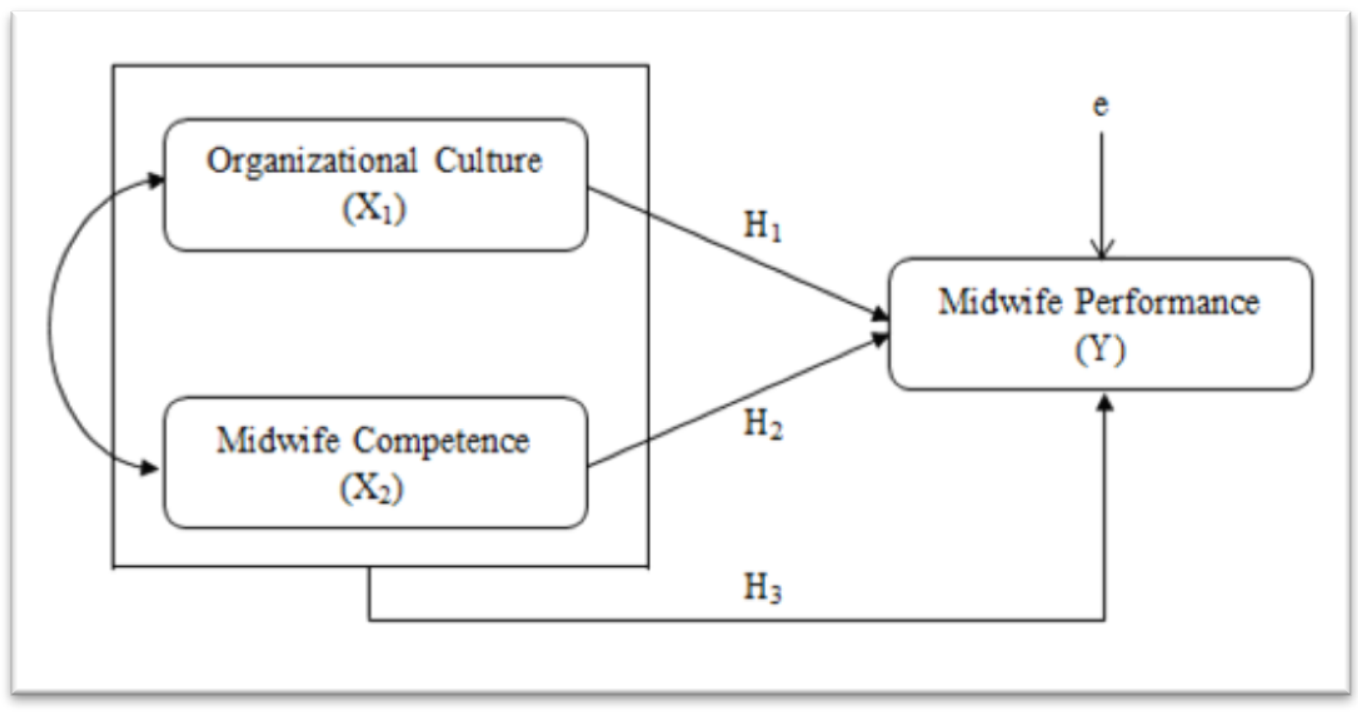

Figure 1:- Conceptual Framework

\section{Based on the research objectives and theoretical reviews, the research hypothesis is:}

1. Organizational culture effect on midwife performance partially.

2. Midwife competence effect on midwife performance partially.

3. Organizational culture and midwife competence on midwife performance simultaneously.

\section{Methods:-}

Approach in this research use quantitative approach with survey method and use path analysis technique. Path analysis is used to analyze the relationship patterns between variables with the aim to determine the direct or indirect effect of a set of independent variables (exogenous) to the dependent variable (endogenous). 
The population in this study were midwives in Community Health Centre in Bungo, Merangin and Tanjung Jabung Barat districts as many as 391 midwives. The determination of the sample was determined based on the theory developed by Slovin. Based on the formula of determining the number of samples from Slovin obtained the number of samples (n) as many as 80 people with value $\mathrm{e}=10 \%$.

Before the analysis, tested the questionnaire instrument with validity and reliability test and test analysis requirements with normality test, homogeneity, and linearity of research variables.

Path analysis is one of the analytical tools developed by (Dillon and Goldstein in Ali Hapzi and Nandan Limakrisna, 2013: 137). Wright developed a method to determine the direct and indirect effects of a variable, where there are exogenous variables and variables that are affected (endogenous variables)

\section{Result And Discussion:- \\ Description of Research Data:-}

Descriptive statistics used are the central symptom sizes that include the highest score, the lowest score, the mean, the values that often appear in the respondent's answer (mode), median value, standard deviation and sample variance. In addition to the central symptom size and data distribution are also used frequency distribution tables and histogram charts. The results of descriptive statistics in the study by using tools SPSS 21.0 as follows:

Table 2:- Descriptive Statistics of Research Variables.

\begin{tabular}{|c|c|c|c|c|}
\hline & $\begin{array}{c}\text { Organizational Culture } \\
\text { X1 }\end{array}$ & $\begin{array}{c}\text { Midwife_Competence } \\
\text { X2 }\end{array}$ & $\begin{array}{c}\text { Midwife_Performance } \\
\text { X4 } 4\end{array}$ \\
\hline \multirow[t]{2}{*}{$\mathrm{N}$} & Valid & 80 & 80 & 80 \\
\hline & Missing & 0 & 0 & 0 \\
\hline \multicolumn{2}{|c|}{ Mean } & 132.50 & 129.20 & 146.90 \\
\hline \multicolumn{2}{|c|}{ Std. Error of Mean } & 1.248 & 1.350 & 1.398 \\
\hline \multicolumn{2}{|c|}{ Median } & 132.37 & 129.071 & 147.125 \\
\hline \multicolumn{2}{|c|}{ Mode } & 131,86 & 128,864 & 147,29 \\
\hline \multicolumn{2}{|c|}{ Std. Deviation } & 11.268 & 12.16 & 12.45 \\
\hline \multicolumn{2}{|c|}{ Variance } & 124.518 & 145.772 & 156.276 \\
\hline \multicolumn{2}{|c|}{ Range } & 55 & 53 & 61 \\
\hline \multicolumn{2}{|c|}{ Minimum } & 104 & 101 & 115 \\
\hline \multicolumn{2}{|c|}{ Maximum } & 159 & 154 & 176 \\
\hline \multicolumn{2}{|c|}{ Sum } & 10563 & 10360 & 11764 \\
\hline
\end{tabular}

Source: Output SPSS under 21.0 for windows

Table 3:- Frequency Distribution of Organizational Cultural Variables $\left(\mathrm{X}_{1}\right)$

\begin{tabular}{|c|c|c|c|c|c|c|c|c|}
\hline No & $\begin{array}{c}\text { Interval } \\
\text { Class }\end{array}$ & $\mathrm{fi}$ & $\begin{array}{c}\mathrm{fi} \\
\text { Kumulatif }\end{array}$ & $x i$ & $x i . f i$ & $x_{1}-\bar{x}$ & $\left(x_{i}-\bar{x}\right)^{2}$ & $f_{i}\left(x_{i}-\bar{x}\right)^{2}$ \\
\hline 1 & $104-111$ & 3 & 3 & 107.5 & 322.5 & -25 & 625 & 1875 \\
\hline 2 & $112-119$ & 6 & 9 & 115.5 & 693 & -17 & 289 & 1734 \\
\hline 3 & $120-127$ & 17 & 26 & 123.5 & 2099.5 & -9 & 81 & 1377 \\
\hline 4 & $128-135$ & 23 & 49 & 131.5 & 3024.5 & -1 & 1 & 23 \\
\hline 5 & $136-143$ & 18 & 67 & 139.5 & 2511 & 7 & 49 & 882 \\
\hline 6 & $144-151$ & 9 & 76 & 147.5 & 1327.5 & 15 & 225 & 2025 \\
\hline 7 & $152-159$ & 4 & 80 & 155.5 & 622 & 23 & 529 & 2116 \\
\hline \multicolumn{2}{|r|}{ Jumlah } & 80 & & & 10600 & - & - & 10032 \\
\hline
\end{tabular}

Based on Table 2 above the mode, median and mean values of organizational culture variables lie in the fourth interval class 128-135. In addition, the number of respondents who get the highest score and the lowest score is balanced so that the data has a tendency to distributed normally. The table above also illustrates that the frequency distribution of organizational culture variables is a symmetric curve. This is indicated by the mode, median and mean scores lying in the fourth interval class. Where the frequency distribution of organizational culture table above also shows that there are 26 respondents $(32.50 \%)$ are below the interval class that contains the average score, 23 
respondents $(28.75 \%)$ are in the interval class that contains the average score And 31 respondents $(38.75 \%)$ were above the interval class which contained the average score.

Table 4:- Variable Frequency Distribution of Midwife Competency $\left(\mathrm{X}_{2}\right)$

\begin{tabular}{|c|c|c|c|c|c|c|c|c|}
\hline No & $\begin{array}{c}\text { Interval } \\
\text { Class }\end{array}$ & $\mathrm{Fi}$ & $\begin{array}{c}\mathrm{fi} \\
\text { Kumulatif }\end{array}$ & $x i$ & $x i . f i$ & $x_{1}-\bar{x}$ & $\left(\boldsymbol{x}_{i}-\overline{\boldsymbol{x}}\right)^{2}$ & $f_{i}\left(x_{i}-\bar{x}\right)^{2}$ \\
\hline 1 & $101-108$ & 3 & 3 & 104.5 & 313.5 & -25 & 610 & 1830.27 \\
\hline 2 & $109-116$ & 10 & 13 & 112.5 & 1125 & -17 & 278.89 & 2788.9 \\
\hline 3 & $117-124$ & 15 & 28 & 120.5 & 1807.5 & -9 & 75.69 & 1135.35 \\
\hline 4 & $125-132$ & 21 & 49 & 128.5 & 2698.5 & -1 & 0.49 & 10.29 \\
\hline 5 & $133-140$ & 16 & 65 & 136.5 & 2184 & 7 & 53.29 & 852.64 \\
\hline 6 & $141-148$ & 10 & 75 & 144.5 & 1445 & 15 & 234.09 & 2340.9 \\
\hline 7 & $149-156$ & 5 & 80 & 152.5 & 762.5 & 23 & 543 & 2714.45 \\
\hline \multicolumn{2}{|c|}{ Jumlah } & 80 & & & 10336 & - & - & 11672.8 \\
\hline
\end{tabular}

Based on Table 2 above the mode, median and mean values of midwife competence variables lie in the fourth interval class 125-132. In addition, the number of respondents who get the highest score and the lowest score is balanced so that the data has a tendency to distributed normally. The above table also illustrates that the frequency distribution of midwife competence variables is a symmetric curve. This is indicated by the mode, median and mean scores lying in the fourth interval class. Where the frequency distribution table of midwives competency above shows also that there are 28 respondents (35\%) are below the interval class that contains the average score, 21 respondents $(26.25 \%)$ are in the interval class that contains the average score, And 31 respondents (38.75\%) were above the interval class containing the average score.

Table 5:- Frequency Distribution of Midwife Performance Variables (Y)

\begin{tabular}{|c|c|c|c|c|c|c|c|c|}
\hline No & $\begin{array}{c}\text { Interval } \\
\text { Class }\end{array}$ & $\mathbf{f i}$ & $\begin{array}{c}\mathbf{f i} \\
\text { Kumulatif }\end{array}$ & $\mathbf{x i}$ & $\mathbf{x i ~ . ~ f i}$ & $\boldsymbol{x}_{\mathbf{1}}-\overline{\boldsymbol{x}}$ & $\left(\boldsymbol{x}_{\boldsymbol{i}}-\overline{\boldsymbol{x}}\right)^{\mathbf{2}}$ & $\boldsymbol{f}_{\boldsymbol{i}}\left(\boldsymbol{x}_{\boldsymbol{i}}-\overline{\boldsymbol{x}}\right)^{\mathbf{2}}$ \\
\hline 1 & $115-123$ & 3 & 3 & 119 & 357 & -27.90 & 778.41 & 2335.23 \\
\hline 2 & $124-132$ & 7 & 10 & 128 & 896 & -18.90 & 357.21 & 2500.47 \\
\hline 3 & $133-141$ & 15 & 25 & 137 & 2055 & -9.90 & 98.01 & 1470.15 \\
\hline 4 & $142-150$ & 24 & 49 & 146 & 3504 & -0.90 & 0.81 & 19.44 \\
\hline 5 & $151-159$ & 19 & 68 & 155 & 2945 & 8.10 & 65.61 & 1246.59 \\
\hline 6 & $160-168$ & 9 & 77 & 164 & 1476 & 17.10 & 292.41 & 2631.69 \\
\hline 7 & $169-177$ & 3 & 80 & 173 & 519 & 26.10 & 681.21 & 2043.63 \\
\hline \multicolumn{2}{|l}{ Jumlah } & $\mathbf{8 0}$ & & & $\mathbf{1 1 7 5 2}$ & - & - & $\mathbf{1 2 2 4 7 . 2}$ \\
\hline
\end{tabular}

Based on Table 2 above the mode, median and mean values of midwife performance variables lie in the fourth interval class of 142-150. In addition, the number of respondents who get the highest score and the lowest score is balanced so that the data has a tendency to distributed normally. The above table also illustrates that the frequency distribution of midwife performance variables is a symmetric curve. This is indicated by the mode, median and mean scores lying in the fourth interval class. Where the distribution table of midwife performance frequency above also shows that there are 25 respondents $(31.25 \%)$ are below the interval class that contains the average score, 24 respondents $(30 \%)$ are in the interval class that contains the average score, and 31 respondents $(38.75 \%)$ were above the interval class containing the average score.

\section{Test requirements Analysis}

Before stepping into hypothesis testing, it must first go through the calculation of analysis requirements. Testing requirements analysis used consisted of three types of test normality, and homogeneity test. The following will be described one by one test results performed.

Normality test. Normality test aims to determine the distribution of the error obtained normal distribution or not. The normality test conducted in the study using Chi Square test. The above normality test results are summarized in Table 6 below. 
Table 6:- Chi Square Normality Test Results

\begin{tabular}{|c|l|c|c|l|}
\hline No & \multicolumn{1}{|c|}{ Variable } & $\boldsymbol{x}_{\text {value }}$ & $\boldsymbol{x}_{\text {table }}$ & \multicolumn{1}{c|}{ Information } \\
\hline 1 & Organizational Culture_X & 1,11 & 12,59 & Normal Distribution \\
\hline 2 & Midwife Competence_X & 1,16 & 12,59 & Normal Distribution \\
\hline 3 & Midwife Performance_Y & 0,28 & 12,59 & Normal Distribution \\
\hline \multicolumn{2}{|r|}{ Normal Requirements $\boldsymbol{x}_{\text {value }}<\boldsymbol{x}^{2}$ table } \\
\hline
\end{tabular}

Based on the results of the calculation of normality test $\mathrm{X}_{1}$ obtained $x_{\text {count }}^{2}$ of $1.11, \mathrm{X}_{2}$ normality test obtained $x_{\text {count }}^{2}$ of 1.16 , and test normality $\mathrm{Y}$ obtained $x_{\text {counted }}^{2} 0.28$. From the calculation result of the above three variables $x^{2}$ count value is obtained which is smaller than $x_{\text {table }}^{2}$ it shows that all variables declared normal distribution, and can proceed for further research.

Homogeneity test. Homogeneity test aims to know that variants are homogeneous or not. Homogeneity test criterion is accept $\mathrm{H}_{1}$ if $x_{\text {count }}^{2}$ the value is smaller than $x_{\text {table }}^{2}$ and accept $\mathrm{H}_{0}$ if $x_{\text {count }}^{2}$ the value is bigger $x_{\text {table with signification }}^{2}$ level $\alpha=0,05$. The homogeneity test results in this study are summarized in the following table:

Table 7:- Homogeneity Test Results of Variance

\begin{tabular}{|c|l|c|c|c|l|}
\hline No & \multicolumn{1}{|c|}{ Description } & dk & \multicolumn{2}{|c|}{$\mathbf{X}^{\mathbf{2}}(\mathbf{0 , 0 5})$} & \multirow{2}{*}{ Result } \\
\cline { 4 - 5 } & & & $\boldsymbol{x}^{2}$ value & $\boldsymbol{x}_{\text {table }}$ & \\
\hline 1 & Y grouped up $\mathrm{X}_{1}$ & 45 & 8,737 & 30,612 & Homogen \\
\hline 2 & Y grouped up $\mathrm{X}_{2}$ & 40 & 3,984 & 26,509 & Homogen \\
\hline
\end{tabular}

Based on the results of the calculation of homogeneity test obtained value $x_{\text {count }}^{2}$ smaller than $x^{2}$ table so that $\mathrm{H}_{1}$ accepted and concluded that all errors in this study showed a homogeneous variance.

Path Analysis:-

This analysis is one option in order to study the dependence of a number of variables within the model. This analysis is a good method to explain if there is a large set of data to analyze and look for causal relationships.

To answer the purpose of research is done by using path analysis (path analysis) by using software tools SPSS version 21.0. The step taken is to calculate the correlation between variables, then based on the calculation of correlation matrix can be calculated path coefficient, the overall influence of $\mathrm{X}_{1}$ to $\mathrm{X}_{2}$ and other variable path coefficients outside variables $\mathrm{X}_{1}$ through $\mathrm{X}_{2}$. Based on the calculation results obtained results as follows.

Table 8:- Coefficients Regression.

\begin{tabular}{|c|c|c|c|c|c|c|}
\hline \multicolumn{7}{|c|}{ Coefficients $^{\mathbf{a}}$} \\
\hline \multirow{2}{*}{\multicolumn{2}{|c|}{ Model }} & \multicolumn{2}{|c|}{$\begin{array}{l}\text { Unstandardized } \\
\text { Coefficients }\end{array}$} & \multirow{2}{*}{$\begin{array}{c}\text { Standardized } \\
\text { Coefficients } \\
\text { Beta }\end{array}$} & \multirow[t]{2}{*}{$\mathrm{t}$} & \multirow[t]{2}{*}{ Sig. } \\
\hline & & $\mathrm{B}$ & Std. Error & & & \\
\hline \multirow[t]{3}{*}{1} & (Constant) & 31.490 & 16.343 & & 1.927 & .058 \\
\hline & Organizational_Culture_X1 & .437 & .101 & .390 & 4.343 & .000 \\
\hline & Midwife_Competence_X2 & .447 & .093 & .431 & 4.799 & .000 \\
\hline
\end{tabular}

Source: Output SPSS under 21.0 for windows 


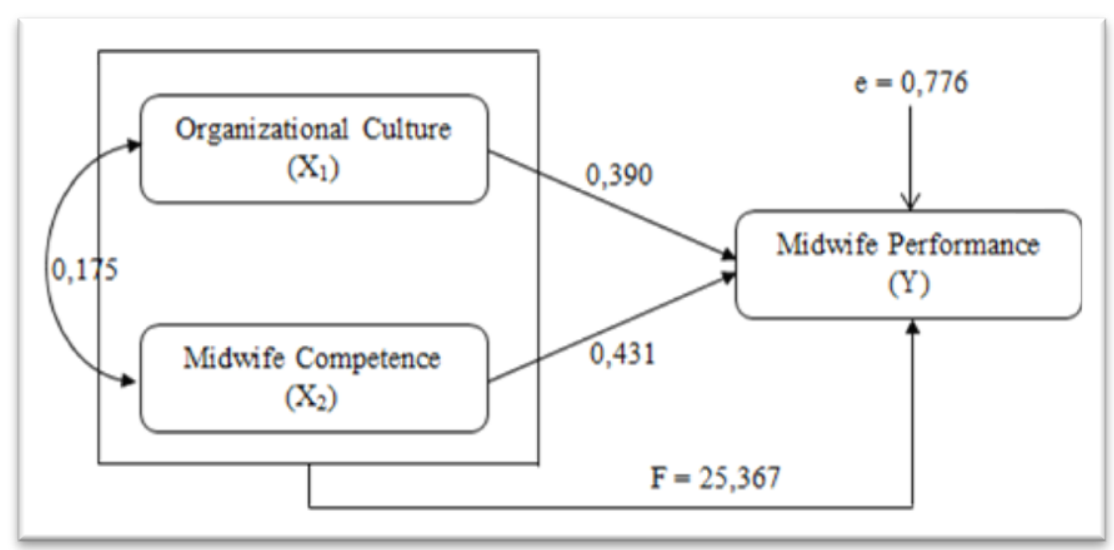

Figure 2:- Results Structure of path analysis.

To see the direct and indirect effects, can be seen in the following table:

Table 9:- Summary of the Coefficients of Organizational Culture and Midwife Competencies On Midwife Performance

\begin{tabular}{|l|r|r|r|r|r|}
\hline \multirow{2}{*}{ Variable } & \multirow{2}{*}{ Directly } & \multicolumn{2}{|c|}{ Indirect } & \multirow{2}{*}{ Sub Total } & \multirow{2}{*}{ Total } \\
\cline { 3 - 5 } & & $\mathbf{X}_{\mathbf{1}}$ & $\mathbf{X}_{\mathbf{2}}$ & & \\
\hline Organizational_Culture_X1 & $15,21 \%$ & & $2,94 \%$ & $2,94 \%$ & $18,15 \%$ \\
\hline Midwife_Competence_X2 & $18,57 \%$ & $2,94 \%$ & & $2,94 \%$ & $21,51 \%$ \\
\hline \multicolumn{4}{|r}{ Influence $\mathbf{X}_{\mathbf{1}}, \mathbf{X}_{\mathbf{2}}$} \\
\hline
\end{tabular}

From the result of path analysis, the direct effect of organizational culture on midwife performance is $15,21 \%$, midwife competence on midwife performance equal to $18,57 \%$ and total influence of organizational culture and midwife competence on midwife performance directly or indirectly equal to 39,66 . The value describes the coefficient of determination $\mathrm{R}^{2}$ Square As shown in the following table.

Tabel 10:- Model summary

\begin{tabular}{|c|c|c|c|c|}
\hline \multicolumn{5}{|c|}{ Model Summary } \\
\hline Model & $\mathrm{R}$ & R Square & Adjusted R Square & Std. Error of the Estimate \\
\hline 1 & $.630^{\mathrm{a}}$ & .397 & .382 & 9.831 \\
\hline
\end{tabular}

Source: Output SPSS under 21.0 for windows

The $\mathrm{R}$ value of 0.630 indicates a double correlation (organizational culture and midwife competency) with midwife performance. Considering the variation of R Square Value of 0.397, it has the meaning of the role or contribution of the organizational culture variable and the competence of the midwife is able to explain the performance variable of the midwife equal to $39,7 \%$. While the rest of $60.3 \%$ influenced by other variables that are not included in this model.

Partial Effect Test Result (t test) and Simultaneous Influence (Test F):-

Hypothesis testing aims to explain the characteristics of certain relationships or differences between groups or the independence of two or more factors in a situation, (Ali Hapzi., and Limakrisna, N., 2013: 72). The partial effect test aims to test whether each independent variable significantly influences the partially bound variable with $\alpha=0.05$ and also the acceptance or rejection of the hypothesis. Partial test ( $t$ test) to answer hypotheses one and two of this study.

Table 11:- $t$ Test Results (Partial)

\begin{tabular}{|c|c|c|c|}
\hline \multicolumn{2}{|c|}{ Model } & t & Sig. \\
\hline 1 & (Constant) & 1.927 & .058 \\
\hline
\end{tabular}




\begin{tabular}{|c|c|c|c|}
\hline & Organizational_Culture_X1 & 4.343 & .000 \\
\cline { 2 - 4 } & Midwife_Competence_X2 & 4.799 & .000 \\
\hline
\end{tabular}

Source: Output SPSS under 21.0 for windows

From Table 11 above, it can be seen that the number of organizational culture variable $\left(\mathrm{X}_{1}\right)$ is 4,343 , because the value of $t$ arithmetic $>t$ table $(4.343>1.665)$ then $\mathrm{H}_{0}$ is rejected and $\mathrm{H}_{1}$ is accepted, it means partially there is significant influence of organizational culture on midwife performance. In addition to test based on significance test, can be seen from the output significance of 0.000 , because the number of significance level more $<0.05(0.000<$ 0.05 ) it can be concluded that organizational culture has a positive and significant impact on the performance of midwives. Thus the first hypothesis is proved and acceptable.

Furthermore, in Table 11 above, it can be seen that t count the midwife competence variable $\left(\mathrm{X}_{2}\right)$ of 4,799 , because the value of $t$ arithmetic > t table $(4.799>1.665)$ then $\mathrm{H}_{0}$ is rejected and $\mathrm{H}_{1}$ accepted, meaning partially there is significant influence of midwives competence on midwife performance. In addition to test based on significance test, can be seen from the significance output of 0.000 , because the level of significance more $<0.05(0.000<0.05)$ it can be concluded that the competence of midwives have a positive and significant impact on the performance of midwives. Thus the second hypothesis is proved and acceptable.

To answer the third hypothesis that the organizational culture and midwife competencies affect the performance of midwives simultaneously can be seen from Table 12 below.

Table 12:- F test results simultaneously

\begin{tabular}{|l|l|r|r|r|r|c|}
\hline \multicolumn{7}{|c|}{ ANOVA $^{\text {a }}$} \\
\hline Model & Sum of Squares & Df & Mean Square & F & Sig. \\
\hline \multirow{3}{*}{1} & Regression & 4903.506 & 2 & 2451.753 & 25.367 & $.000^{\text {b }}$ \\
\cline { 2 - 6 } & Residual & 7442.294 & 77 & 96.653 & & \\
\cline { 2 - 6 } & Total & 12345.800 & 79 & & & \\
\hline
\end{tabular}

Source: Output SPSS under 21.0 for windows

From the anova or F test as shown in Table 12, the value of $\mathrm{F}$ count is 25.367 with a probability value of p-value of 0.000 , because the value of $\mathrm{F}$ count $>\mathrm{F}$ table $(25.367>3.11)$ so it can be concluded that the null hypothesis $\left(\mathrm{H}_{0}\right)$ is rejected and The alternative hypothesis $\left(\mathrm{H}_{1}\right)$ is accepted, meaning that there is a significant influence between organizational culture and midwife competence together effect on midwife performance. Thus the third hypothesis is accepted.

\section{From the interpretation of the above data it can be discussed that:-} Organizational Culture on Midwife Performance:-

Organizational culture has significant effect on midwife's performance. These findings indicate that if a positive organizational culture is exercised, maintained and developed within an organization will be able to contribute positively to midwife performance.

The results of this study showed similar results with research conducted by Porwani, S. (2010) entitled The Influence of Organizational Culture on Employee Performance. Where the results of his research shows that organizational culture has a positive and significant impact on performance. Without an organizational culture, one tends to feel reluctant to perform a task well regardless of its status within the organization, due to a lack of commitment agreements.

In addition, this research is also supported by Taurisa, CM, and Ratnawati, I. (2012) entitled Analysis of Organizational Culture Influence and Job Satisfaction To Organizational Commitment In Improving Employee Performance (Study at PT Sidomuncul Kaligawe Semarang) where the results also show the results The same organizational culture that has a positive and significant influence on employee performance. 
The findings provide an understanding that a midwife in carrying out the service must be supported by an organizational culture. This means that the better the organizational culture in an institution will increasingly affect the performance of a midwife. Therefore, the existing organizational culture in the puskesmas must be able to give birth to a good organizational culture.

Organizational culture becomes the norm, trust, value and practice to all members of the organization. This includes the ways in which a person communicates within an organization such as calling the name of a co-worker, the way of speaking, dressing, the value of work, and so on. The birth of a positive or negative organizational culture depends on the policy of the board or head of the organization. Organizational culture is very complex and needs to have shared norms and values that guide the behavior of members. Luthans (2009: 125) says that organizational culture must have recognized and respected behavioral order characteristics, the existence of norms, dominant values, philosophy, rules and organizational mood.

\section{Midwives Competency on Midwife Performance:-}

Midwife competence has direct effect to midwife's performance. These findings indicate that good competence, executed, and developed within an organization will be able to contribute positively to the midwife's performance spirit.

The results of this study show the same results with research conducted by Suswati, E., Winarno, D., and Idrus, AMS., Midwife Entrepreneurship: Competence and Performance Work Environment as Determinant. Where the results of his research shows that competence has a positive and significant effect on employee performance.

The findings provide an understanding that midwife performance should prioritize its competence, meaning that the better the competence of midwives in an organization will be better on the performance of the midwife itself. Therefore, midwives must continue to improve their competence and get used to doing all their duties in accordance with professional standards and professional ethics in accordance with the 1464th Regulation of 2014

Based on these competencies, midwives can apply their knowledge and skills in providing midwifery care according to client / patient needs. Maternal safety and well-being is the most important concern for the midwife. Midwives in providing health services are responsible and accountable for their practice. In carrying out the practice, the midwife is often confronted in the question of what the midwife does and how he or she works. To answer the question should be emphasized the competence of support that must be owned by midwife.

Organizational Culture and Midwife Competency on Midwife Performance.

The organizational culture and competence of the midwife influence the performance of the midwife. The findings provide an understanding that the performance of a midwife in carrying out the service should be supported by the organizational culture and competence of the midwife. This means that the better the organizational culture and competence of midwives in an institution will increasingly affect the performance of the midwife. Therefore, good organizational culture and competence in health center must be able to give birth to a good midwife performance.

Midwife performance consists of dimension and or indicator: Deepening religion and profession; Trust in working; Behavior in work; Employment Opportunity; Achieving good in work; Effectiveness and Results of work; And work efficiency. Organizational culture consists of dimensions and or indicators: Organizational Rules; Orientation to the environment; Decision-making style. Midwife competence consists of dimension and or indicator that is: Knowledge; Skills; And Behavior.

\section{Conclussion:-}

\section{Based on the results and discussion then the conclusion of this study is:-}

1. Organizational culture has a positive and significant effect on the performance of the midwife partially. Organizational culture consisting of dimensions: Organizational Rules; Orientation to the environment; Decision-making style. The stronger positive organizational culture that is run, maintained and developed within an organization will be able to make a positive contribution to the performance of the midwife.

2. Midwife competence has a positive and significant effect on partial midwife performance. Competencies consisting of dimensions: Knowledge; Skills; And Behavior. The better the competence of midwives will be able to make a positive contribution to the performance spirit of the midwife. 
3. Organizational culture and competence of midwives have a positive and significant impact on midwife performance. The better the organizational culture and competence of midwives in an institution will increasingly affect the performance of midwives.

\section{Sugestion:-}

Based on data analysis, statistical calculation process, empirical research model test and discussion of study results conducted, submitted some suggestions as follows:

1. The need to improve human resources through education and training for all health workers, especially midwives on Organizational Behavior and ethics to open the thinking and development of self-quality of midwives on a regular basis. One of the role and function of the midwife is as the manager and the educator must have a good personality and can be a good role model for society and people in their environment, such as training of midwifery service so that midwives can provide optimal and standardized midwifery services.

2. It is expected that the Head of Community Health Centre or all policy holders can create a conducive organizational culture, through emotional and spiritual intelligence training and open-nature management training, so as to encourage the emergence of high work motivation in every midwife working at Community Health Centre. With high work motivation will make them have a strong drive to develop good performance. Thus the vision and mission of the Community Health Centre can be achieved.

3. Researchers in the field of education management and human resources can undertake a more comprehensive review of the variables that can affect both directly and indirectly the midwife's performance.

\section{References:-}

1. Ahmad. (2016). Influence of Transformational leadership, organizational culture and work motivation of Employee to Employee Job Satisfaction and its implication on PDAM Officer performance in Banten Province. Dissertation of Pasundan University of Bandung.

2. Aima, Havidz and Ali Hapzi, et al., 2017. Model of Employee Performance: Competence Analysis and Motivation (Case Study at PT Bank Bukopin, Tbk Center). Quest Journals Journal of Research in Business and Management, ISSN (Online): 2347-3002. Volume 4 Issue 11 (2017) pp: 49-59. Www.questjournals.org

3. Ali Hapzi, H., Limakrisna, N. (2013). Research Methodology Issue 1, Cet. 1, Deepublish, Yogyakarta.

4. Dhermawan, A.A.N.B., Sudibya, I.G.A., and Utama, I.W.M. (2012). The influence of motivation, work environment, competence and compensation on job satisfaction and performance of employees in the Office of Public Works Office of Bali Province. Journal of Management, Business Strategy and Entrepreneurship Vol. 6, No. 2.

5. Judges, A., and Hadipapo, A. (2015). Role of Leadership and Organizational Culture to Human Resource Performance in Wawotobi. Journal of Ecobics. Vol. 16, No. 1.

6. Kreitner, R., and Kinicki, A. (2014). Organizational behavior. Jakarta: Salemba Four. 2014.

7. Linawati and Suhaji. (2012). The influence of motivation, competence, leadership and work environment on employee performance (Study at PT Herculon Carpet Semarang).

8. Luthans, F. (2009). Organizational behavior. Issue 10. Yogyakarta: Andi.

9. Maslukhan, F. (2015). The Influence of Organizational Culture on Employee Performance (Case Study At Surakarta Islamic Hospital). Manuscript Publication of Muhammadiyah University of Surakarta.

10. Central Board of Indonesian Midwife Association (IBI), Ethics and Code of Ethics of Midwifery, Jakarta: Central Board of Indonesian Midwives Association (Ikatan Bidan Indonesia). 2006

11. Health Ministerial Regulation (PERMENKES) Number 572 of 1996

12. Porwani, S. (2010). The Influence of Organizational Culture on Employee Performance. Scientific journals. Vol. 11, No. 2.

13. Rinawati, S.I and Ingsih, K. (2013). The Effect Of Work Environment And Competence On Employee Performance With Motivation As Intervening Variable At Specific Non-Vertical Working Units (SNVT) Ministry Of Public Works In Semarang. Journal of Dian Nuswantoro University.

14. Robbins, S.P. (2010). Organizational Behavior, Tenth Edition. New Jersey: Prentice Hall.

15. Secretariat of the MDGs. Status of Achieving MDGs in Indonesia. Sekretariatmdgs.or.id

16. Sembiring, M. (2012). Culture and Organizational Performance. Bandung: Media Focus. Spencer, L.M. Jr., and Spencer, S.M. (2010). Competence at Work, New York: John Wiley \& Sons, Inc.

17. Suswardji, E., Hasbullah, R., and Albatross, E. (2012). Relation of Competence and Work Discipline on Performance of Educational Staff of Singaperbangsa Karawang University. Journal of Management. Vol. 10 No. 1. 
18. Suswati, E., Winarno, D., and Idrus, HMS. (2015). Midwife Entrepreneurship: Competence and Performance Work Environment as Determinant. University of Gajayana Malang, Universitas Brawijaya Malang, Indonesia, Journal International.

19. 20. Taurisa, C.M., and Ratnawati, I. (2012). Analysis of Organizational Culture Influence and Job Satisfaction To Organizational Commitment In Improving Employee Performance (Study at PT Sido uncul Kaligawe Semarang). Journal of Business and Economics (JBE). Vol. 19, No. 2.

20. Vecchio, R.P. (2007). Organizational Behavior. Orlando: Harcourt Brace \& Company.

21. Wibowo. (2013). Work management. Jakarta: PT. Raja Grafindo Parsada.

22. Wilson, B. (2012). Human Resource Management. Jakarta: Erland. 